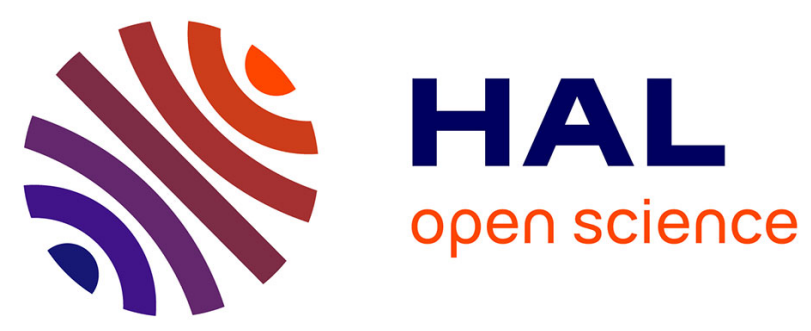

\title{
Synthesis and Characterization of a Novel Bis-Sulfoxide and Its Evaluation as a Ligand in P-Block Chemistry
}

Noémi Deak, Olivier Thillaye Du Boullay, Sonia Mallet-Ladeira, Ionuţ-Tudor Moraru, David Madec, Gabriela Nemes

\section{- To cite this version:}

Noémi Deak, Olivier Thillaye Du Boullay, Sonia Mallet-Ladeira, Ionuţ-Tudor Moraru, David Madec, et al.. Synthesis and Characterization of a Novel Bis-Sulfoxide and Its Evaluation as a Ligand in P-Block Chemistry. European Journal of Inorganic Chemistry, 2020, 10.1002/ejic.202000728 . hal-02971237

\section{HAL Id: hal-02971237 \\ https://hal.science/hal-02971237}

Submitted on 19 Oct 2020

HAL is a multi-disciplinary open access archive for the deposit and dissemination of scientific research documents, whether they are published or not. The documents may come from teaching and research institutions in France or abroad, or from public or private research centers.
L'archive ouverte pluridisciplinaire HAL, est destinée au dépôt et à la diffusion de documents scientifiques de niveau recherche, publiés ou non, émanant des établissements d'enseignement et de recherche français ou étrangers, des laboratoires publics ou privés. 


\title{
Synthesis and Characterization of a Novel Bis-Sulfoxide and Its Evaluation as a Ligand in P-Block Chemistry
}

\author{
Noémi Deak, ${ }^{[a, b]}$ Olivier Thillaye du Boullay, ${ }^{[a]}$ Sonia Mallet-Ladeira, ${ }^{[c]}$ Ionuț-Tudor Moraru, ${ }^{[b]}$ \\ David Madec, ${ }^{*[a]}$ and Gabriela Nemes*[b]
}

6

Abstract: A new aryl bis-sulfoxide derivative was designed, synthetized and structurally characterized in solution and in solid state. The chemical behaviour of the newly obtained 1,3(para-tolylsulfinyl)-5-tert-butyl-benzene $\mathbf{2}$ was evaluated to- wards tin, silicon and phosphorus containing derivatives. In the case of Sn(II) derivative, the potential of bis-sulfoxide 2 as a 11 pincer type ligand was suggested.

\section{Introduction}

The importance of compounds containing sulfinyl groups gained focus lately thanks to their proven role in organic syn-

16 thesis, catalysis, pharmaceutical or material chemistry. ${ }^{[1-5]}$ These compounds are successfully used in catalytic reactions, or as reagents in asymmetric synthesis. ${ }^{[3-8]}$

Derivatives containing two sulfinyl groups with different roles, in the chemical processes are also known. For example,

21 the bis-sulfoxide derivatives are used as ligands in the stabilisation of transition metal or lanthanide complexes or as ligand in transition metal-catalyzed reactions or in various catalytic processes. ${ }^{[5,7,9-18]}$ In most of the cases the coordination to the metal center is realized through the sulfur atom of the sulfinyl

26 group, ${ }^{[5,11,14,15,18-23]}$ however, coordination through the oxygen atom is also a possibility, some examples are presented in the literature. ${ }^{[12,14,23-26]}$

The synthesis of the sulfoxides can be realized by different methods such as the arylation of sulfenate anions by a coupling

31 reaction, a nucleophilic substitution or an electrophilic attack, with the formation of a C-SO bond, ${ }^{[27-31]}$ or by oxidation of a sulfide through a thioether as intermediary derivative. ${ }^{[32-39]}$

[a] Dr. N. Deak, O. Thillaye du Boullay, Dr. D. Madec

Laboratoire Hétérochimie Fondamentale et Appliquée (UMR 5069), Université de Toulouse, CNRS,

118 Route de Narbonne, 31062 Toulouse, France

E-mail: madec@chimie.ups-t/se.fr

http://www.lhfa.cnrs.fr

[b] Dr. N. Deak, I.-T. Moraru, Prof. Dr. G. Nemes

Facultatea de Chimie si Inginerie Chimica, Universitatea Babes-Bolyai, str. Arany Janos, nr. 11, 400028, Cluj-Napoca, Romania

E-mail: gabriela.nemes@ubbcluj.ro

http://www.chem.ubbcluj.ro/pagini/anorganica/clcpe/

[c] S. Mallet-Ladeira

Institut de Chimie de Toulouse, FR2599, Université Paul Sabatier, UPS, 118 Route de Narbonne, 31062 Toulouse, France

Supporting information and $O R C I D(s)$ from the author(s) for this article are

available on the WWW under https://doi.org/10.1002/ejic.202000728.

This manuscript is part of the Special Collection Pincer Chemistry and Catalysis.
The most common method of obtaining sulfoxides is by oxidation of thioethers ${ }^{[5]}$ using various oxidizing agents. ${ }^{[3,4]}$ It is challenging to obtain a selective oxidation, because there is 36 the possibility of obtaining both the sulfoxide and the sulfone moieties. However, several methods were developed for selective oxidation, obtaining only a sulfoxide unit. ${ }^{[3,4]}$

Following our scientific interest focused on the synthesis of new organic compounds that can function as O,C,O-chelating 41 aryl-pincer-type ligands, containing either two sulfonyl groups in their structure (bis-sulfone), ${ }^{[40,42]}$ or one sulfonyl and one sulfinyl moiety (sulfone-sulfoxide), ${ }^{[43]}$ we have expanded our research on the bis-sulfoxides derivatives having in mind their ability to stabilize metallylenes. A significant feature of the sulf- 46 oxide groups connected to an aromatic ring, that is considered in this work, is their powerful directing effect in ortho position, as it is well known in the literature. ${ }^{[2]}$ We envisioned a derivative, where the synergistic effect of the ortho-directing sulfoxide group and the bulky tBu group, connected in para position of 51 the central aromatic ring (blocking the meta positions, that are also ortho position considering the sulfinyl groups), would lead to the selective deprotonation in the ortho position $(C 1)$ in the presence of deprotonating agents. ${ }^{[40,41]}$ This characteristic of the bis-sulfoxide derivative makes it ideal for the role of an 56 $\mathrm{O}, \mathrm{C}, \mathrm{O}$-chelating ligand. To the best of our knowledge, there are no examples of ligands containing sulfinyl moieties used for the stabilization of group 14 metallylenes beside the recently reported germylene-sulfoxide ligand used for obtaining transition metal complexes. ${ }^{[44]}$

In this study we present the synthesis and the structural characterization of the new bis-sulfoxide derivative 1,3-(paratolylsulfinyl)-5-tert-butyl-benzene $\mathbf{2}$ and its reactivity towards heavy elements of the $p$ block, such as Si(IV), Sn(II) and P(III).

\section{Results and Discussion}

The new bis-sulfoxide compound, 1,3-(para-tolylsulfinyl)-5-tertbutyl-benzene $\mathbf{2}$ was obtained through an oxidation reaction of the newly obtained bis-thioether $\mathbf{1}$. (Scheme 1). 


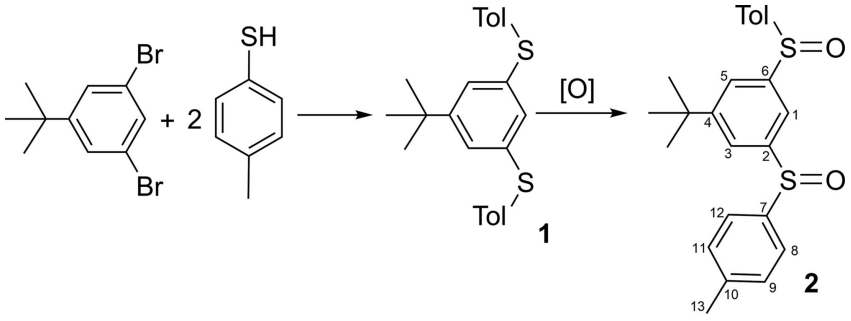

Scheme 1. Synthesis of bis-thioether 1 and bis-sulfoxide $\mathbf{2}$.

In its turn, derivative $\mathbf{1}$ was obtained, by a cross-coupling

71 reaction of 1,3-dibromo-5-tert-butylbenzene and para-toluene thiol, catalysed by a palladium-xantphos complex, using a modified method described in literature. ${ }^{[29]}$

The bis-thioether 1, used as starting product, was isolated as a white powder and completely characterized by NMR spectro76 scopy and X-ray analysis. The ${ }^{1} \mathrm{H}$ NMR spectrum showed characteristic signal for the $\mathrm{H} 1$, a triplet at $\delta=6.82\left({ }^{4} J_{H H}=1.7 \mathrm{~Hz}\right)$, while in the ${ }^{13} \mathrm{C}$ NMR the signal for the $\mathrm{C} 1$ atom is at $126.9 \mathrm{ppm}$. Suitable crystals for X-ray diffraction were obtained in $\mathrm{CH}_{2} \mathrm{Cl}_{2}$. The solid-state structure of $\mathbf{1}$ is shown in Figure 1, together 81 with the most significant geometrical parameters.

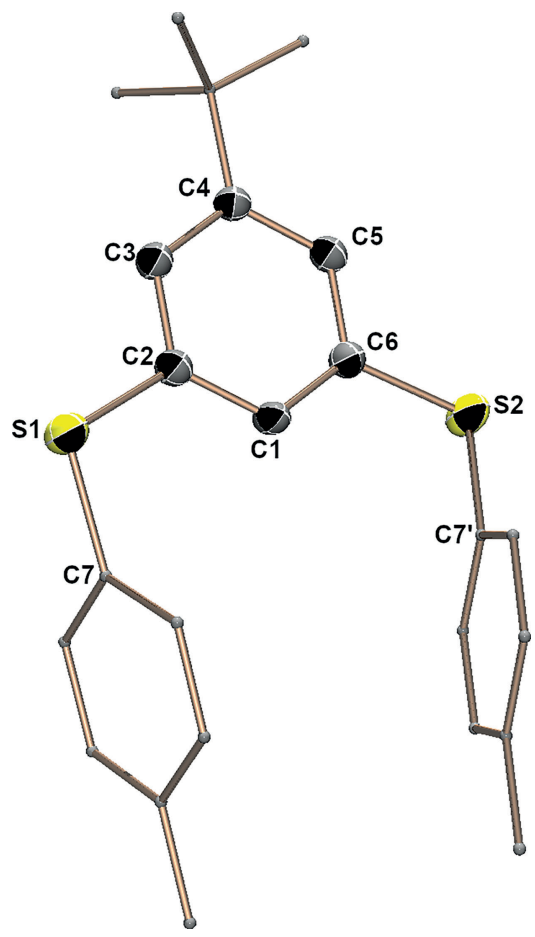

Figure 1. Solid state structure of 1,3-(para-tolyl sulfide)-5-tert-butyl-benzene 1 (50\% probability level for the thermal ellipsoids). For clarity, hydrogen atoms are omitted, tolyl and tert-butyl groups are simplified. Selected bond lengths $[\AA ̊]$ and angles [deg]: C2-S1 1.771(2) S1-C7 1.777(2),C6-S2 1.773(2), S2-C7' 1.771(2), C2-S1-C7 103.76(10), C6-S2-C7' 103.01(10).

The bis-thioether 1 crystallizes in the orthorhombic space group $\left(P 2{ }_{1} 2_{1} 2_{1}\right)$, with three molecules in the unit cell. Since all three molecules present similar geometric parameters data for one molecule is presented. It is to note that the tolyl groups

86 are placed in an almost parallel position with the $\mathrm{C}-\mathrm{S}-\mathrm{C}$ bond angle at $103^{\circ}$.
The bis-thioether 1 was oxidized to obtain a mixture of 1,3(para-tolylsulfinyl)-5-tert-butyl-benzene $\mathbf{2}$ together with the previously described bis-sulfone ${ }^{[40]}$ and sulfone-sulfoxide, ${ }^{[43]}$ derivatives previously reported by our team. Though in the lit- 91 erature several studies are presented on the oxidation of sulfides to sulfoxides or sulfones using different solvents, catalysts and oxidants, on various substrates, ${ }^{[3-5,14,32,35,36,45]}$ none of them mention the selective formation of a sole compound in the case when two sulfide groups are present in the molecule. 96 In order to obtain bis-sulfoxide $\mathbf{2}$, two oxidation methods were tested, following procedures described in the literature ${ }^{[38,46,47]}$ but adapted to the present case; one where the oxidation is realized by adding hydrogen-peroxide to the bis-thioether 1 in anhydrous acetic acid, and a second method, where mCPBA 101 was added to a solution of the new bis-thioether 1 in $\mathrm{CH}_{2} \mathrm{Cl}_{2}$. The second method proved to be more efficient, affording not only slightly higher yield, but considerably lower reaction time, one hour compared to 24 hours. Bis-sulfoxide $\mathbf{2}$ was purified by column chromatography using as eluent either a mixture of 106 cyclohexane and ethyl acetate (8:2) or toluene and ethyl acetate (8:2). The new bis-sulfoxide $\mathbf{2}$ was separated as a mixture of 50$50 \%$ of the meso and $d l$ diastereomers, according to the ${ }^{1} \mathrm{H}$ NMR studies.

The $d l$ diastereomer could be separated from the mixture in 111 a small quantity by fractional crystallization in acetone. It was characterized by NMR spectroscopy and single-crystal X-ray diffraction.

In the ${ }^{1} \mathrm{H}$ NMR spectra a downfield shift can be observed for the $\mathrm{H} 1$ from $6.82 \mathrm{ppm}$ in the bis-thioether 1 to $7.50 \mathrm{ppm}$ (dl 116 isomer, $\mathrm{t},{ }^{4} J_{\mathrm{HH}}=1.6 \mathrm{~Hz}$ ) and $7.58 \mathrm{ppm}$ (meso isomer, $\mathrm{t},{ }^{4} \mathrm{~J}_{\mathrm{HH}}=$ $1.6 \mathrm{~Hz}$ ) in bis-sulfoxide $\mathbf{2}$, which suggests the presence of the sulfinyl groups. After the assignment of the signals in the ${ }^{1} \mathrm{H}$ NMR of bis-sulfoxide 2- $d$ l with two dimensional NMR analysis, the signals for the meso isomer could also be assigned. The 121 numbering scheme used in NMR analysis is presented in Scheme 1.

The ratio of each diastereomer was determined from the ${ }^{1} \mathrm{H}$ NMR, where the signals for the $\mathrm{H} 3$ and $\mathrm{H} 5$ appear as two doublet signals at 7.71 and $7.74 \mathrm{ppm}\left({ }^{4} J_{H H}=1.6\right.$ and $\left.1.6 \mathrm{~Hz}\right)$, which 126 can be distinguished very easily. In the case of the signals for the other protons, these overlap in some part.

The signals for the meso and $d l$ isomers of bis-sulfoxide 2 in the ${ }^{13} \mathrm{C}$ NMR spectra are very close of each other, with a difference of $0.02-0.1 \mathrm{ppm}(0.77-10.41 \mathrm{~Hz})$.

Crystals of the bis-sulfoxide $\mathbf{2}-d l$ suitable for X-ray analysis were separated from acetone and the molecular solid-state structure is presented in Figure 2.

Bis-sulfoxide $\mathbf{2}$ crystallizes in a monoclinic space group (C 2/c), (with a molecule of acetone in the crystal lattice) and 136 the structure shows that tolyl groups of the bis-sulfoxide are situated on the same side of the central aromatic ring. The $\mathrm{S}=\mathrm{O}$ bond lengths of 1.499(1) $\AA$ and 1.493(1) $\AA$ are in the range of $\mathrm{S}=\mathrm{O}$ bonds found in sulfoxides presented in the literature

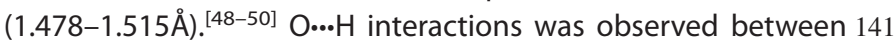
the $\mathrm{O}$ atoms of the sulfoxide groups and the $\mathrm{H}$ atoms of the

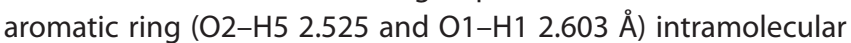




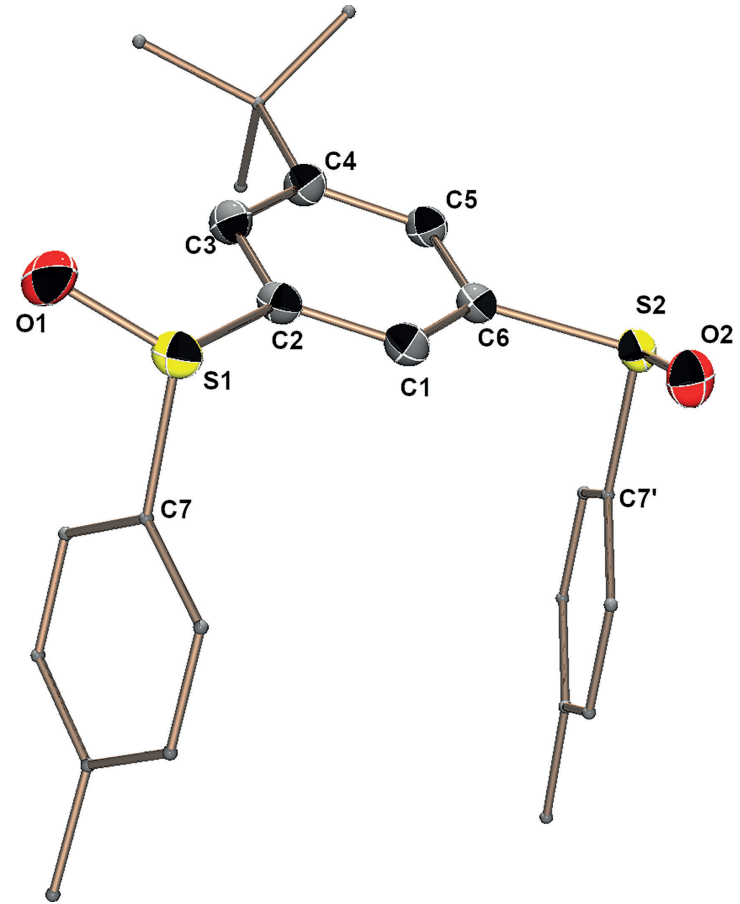

Figure 2. Molecular structure of compound 2-dl in solid state $50 \%$ probability level for the thermal ellipsoids). For clarity, the solvent and hydrogen atoms are omitted; tolyl and tert-butyl groups are simplified. Selected bond lengths [Å] and bond angles [deg]: S1-O1 1.493(1); S2-O2 1.499(1); O1-S1C2 106.80(6), O2-S2-C6 106.42(6); C1-C6-S2 118.71(9). short contacts similar to those found for sulfoxides 2.35$2.97 \AA .{ }^{[49]}$

The separation of the two diastereomers of bis-sulfoxide $\mathbf{2} 146$ was attempted through an HPLC experiment (see details in ESI, Figure S25) on a chiral column and it was shown that it is possible to separate the $d l$ and the meso diastereomers, but also the $d$ - and $l$-enantiomers. However, the experiment was performed on an analytical column, and so far, it could not be realized on 151 a bigger scale.

DFT calculations were performed on the diastereomers of bis-sulfoxide $\mathbf{2}$ in order to gain further insight on their stability, isomerization and racemization barriers. The optimized molecular structures of all possible isomers of derivative $\mathbf{2}$ are illus- 156 trated in Figure 3. Their computed relative energies are also depicted. However, energy gaps between isomers are very small, calculated differences among the investigated series being of at most $0.4 \mathrm{kcal} \mathrm{mol}^{-1}$ (see Figure 3). It is thus expected that all species would coexist in solution at room temperature. 161 In addition, cis-trans isomerization barriers were assessed by means of DFT investigations, for both meso and $d /$ diastereomers (Figure S26 and S27). As expected, cis-trans transformations are barrier-less, with calculated rotation barriers of at most $2 \mathrm{kcal} \mathrm{mol}^{-1}$.

Racemization barriers of the investigated enantiomers were also calculated by DFT means. To the best of our knowledge there is no previous theoretical study assessing racemization barriers on bis-sulfoxide species. However, racemization mecha-

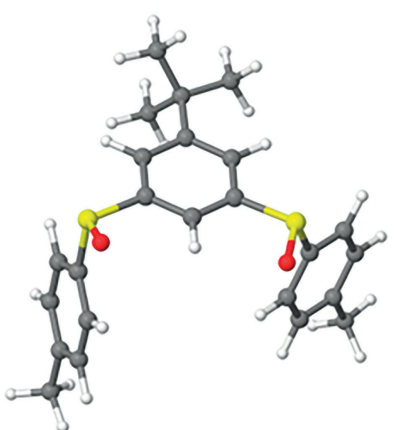

CIS meso 1 $\left(\Delta E=0.4 \mathrm{kcal} \mathrm{mol}^{-1}\right)$

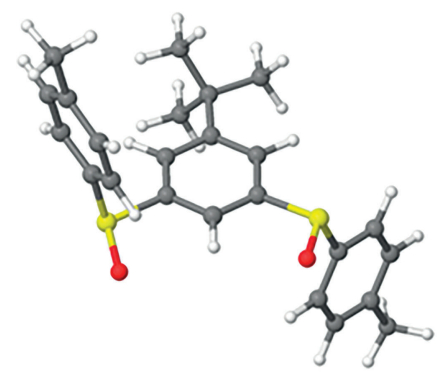

TRANS dI 1 $\left(\Delta E=0.4 \mathrm{kcal} \mathrm{mol}^{-1}\right)$

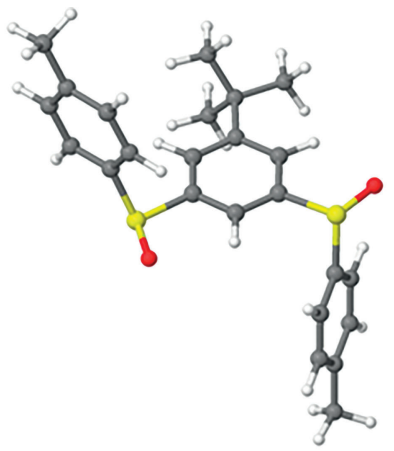

TRANS meso $\left(\Delta E=0.0 \mathrm{kcal} \mathrm{mol}^{-1}\right)$

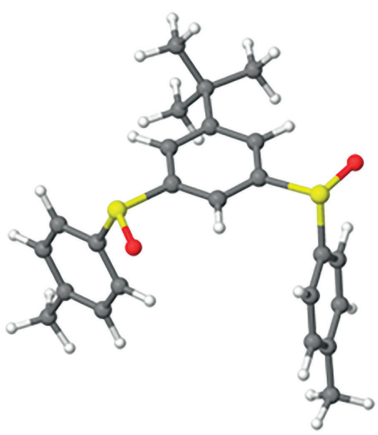

CIS dl $\left(\Delta E=0.0 \mathrm{kcal} \mathrm{mol}^{-1}\right)$

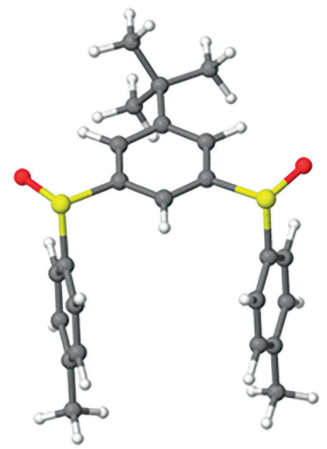

CIS meso 2 $\left(\Delta E=0.2 \mathrm{kcal} \mathrm{mol}^{-1}\right)$

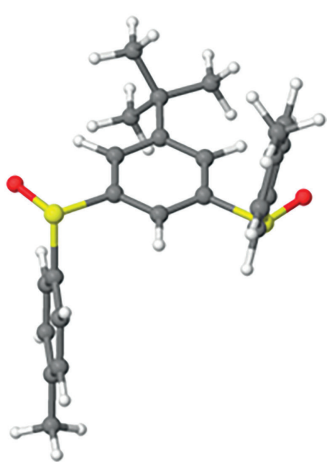

TRANS dI 2 $\left(\Delta E=0.2 \mathrm{kcal} \mathrm{mol}^{-1}\right)$

Figure 3. DFT optimized molecular structures of all possible diastereomers of bis-sulfoxide 2. Computed relative energies are also depicted (all displayed energies contain thermal enthalpy corrections). 
171 nisms on sulfoxide molecules are well documented. The pioneering work of Mislow and co-workers revealed several possible racemization pathways of sulfoxide derivatives, involving either pyramidal inversion or either homolytic C-S bond breaking. ${ }^{[51-52]}$ In addition, it has been shown than benzyl- and alyl-

176 sulfoxides undergo more complex rearrangement mechanisms. ${ }^{[53-54]}$ Subsequent computational explorations performed on sulfoxide molecules brought further clarification on the racemization mechanism of these species, highlighting an enhanced kinetic accessibility for the pyramidal inversion pathway

181 than for the $\mathrm{C}-\mathrm{S}$ bond cleavage one. ${ }^{[55]}$ Concerning the racemization of the bis-sulfoxide enantiomers, we have considered in the present DFT study both the pyramidal inversion and the homolytic bond dissociation routes. However, calculations emphasize that the pyramidal inversion pathway requires a signifi-

186 cantly lower barrier than the homolytic bond cleavage route. The energy gap between the computed barriers of the two mechanisms is of ca. $18 \mathrm{kcal} \mathrm{mol}^{-1}$ (see Figure S28 for comparisons). Figure 4 illustrates the racemization route, occurring via pyramidal inversion, for the cis enantiomers of the bis-sulfoxide

191 derivative. Inter-conversion of the two enantiomers involves the meso trans derivative, as an intermediate, whereas the computed transition states (TS) structures, corresponding to the pyramidal inversion of the sulfur atoms of each of the sulfoxide groups, display the same energy. The TS structures display trig-

196 onal planar geometries at the sulfur atom. The computed racemization barrier for the cis bis-sulfoxide enantiomers is of $35.9 \mathrm{kcal} \mathrm{mol}^{-1}$. Barrier heights of the same order of magnitude were additionally calculated for the inter-conversion of the trans enantiomers ( $36 \mathrm{kcal} \mathrm{mol}^{-1}$, see Figure S29 for details). Notewor-

201 thy, the computed racemization barriers of these bis-sulfoxides enantiomers are in line with previously reported values for the pyramidal inversion of mono-sulfoxide species, for which barrier heights of 38.7-47.1 kcal mol ${ }^{-1}$ were obtained. ${ }^{[55]}$

In order to demonstrate the reactivity of bis-sulfoxide $\mathbf{2}$ derivative, a deprotonation experiment was realized. The deproto- 206 nation reaction of the $\mathrm{H} 1$ occurs selectively in the presence of LDA, due to the fact that the two sulfinyl groups have strong ortho director effect, thus favouring lithiation in this position. The carbanion of the bis-sulfoxide ligand was obtained by adding LDA to a solution of bis-sulfoxide 2 (50\% dl and $50 \%$ meso 211 mixture calculated from the ${ }^{1} \mathrm{H}$ NMR) in THF at low temperature.

To find the optimal conditions for the deprotonation, the lithiated derivative 3 (Scheme 2) was quenched with $\mathrm{D}_{2} \mathrm{O}$. The ${ }^{1} \mathrm{H}$ NMR spectra of the deuterated compound $\mathbf{4}$ showed that the deprotonation is complete and almost quantitative $(<5 \% 216$ starting material left). The efficiency of the deprotonation was followed by the disappearance of the triplet signal at $7.58 \mathrm{ppm}$ for the $\mathrm{H} 1$ in the ${ }^{1} \mathrm{H}$ NMR of the $d$-isomer of bis-sulfoxide 2 (the signal for the $\mathrm{H} 1$ proton of the meso isomer at $7.50 \mathrm{ppm}$ is overlapping with other signals, it's disappearance cannot be 221 followed as clearly).

Considering that the stabilization of group 14 metallylenes with different type of ligands is a continuing interest for our group, ${ }^{[51-59]}$ we evaluated the O,C,O pincer-type ligand behaviour of bis-sulfoxide 2 towards Sn(II). In this respect, lithium 226 derivative $\mathbf{3}$ was treated with $\mathrm{SnCl}_{2}$ at low temperature, and the formation of the bis-sulfoxide stannylene [2,6-(para-tolylsulfinyl)-4-tert-butyl-phenyl-chlorostannylene] $\mathbf{5}$ was confirmed by ${ }^{1} \mathrm{H}$ NMR spectroscopy, where the disappearance of the triplet signal at $7.58 \mathrm{ppm}$ for the $\mathrm{H} 1$ proton of the $\mathrm{dl}$-isomer bis-sulfox- 231 ide 2 is observed (the signal for the $\mathrm{H} 1$ proton of the meso isomer at $7.50 \mathrm{ppm}$ is overlapping with other signals, it's disap-

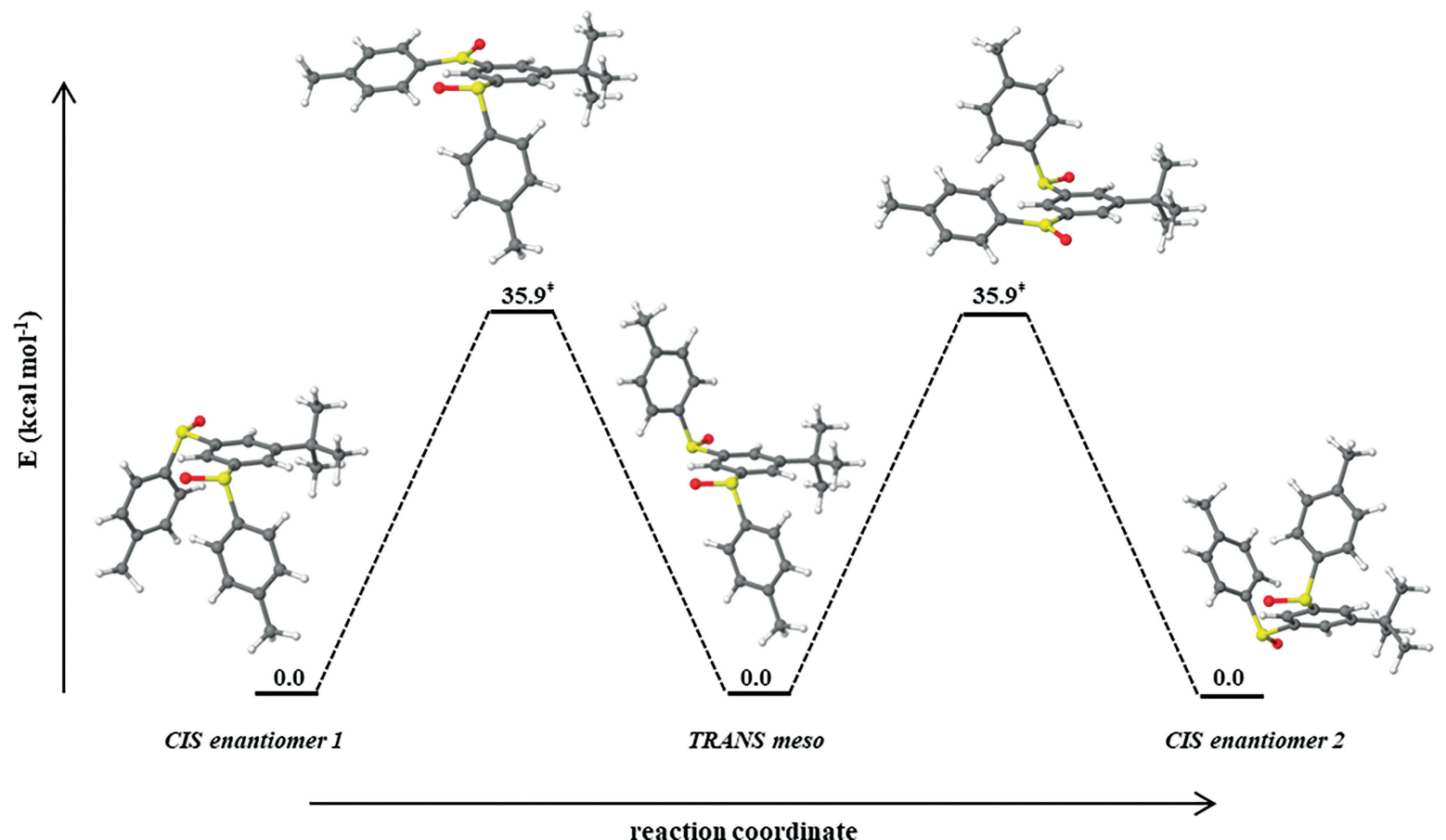

Figure 4. Racemization pathway suggested for the cis enantiomers of bis-sulfoxide $\mathbf{2}$; the mechanism occurs via sulfur pyramidal inversion. 


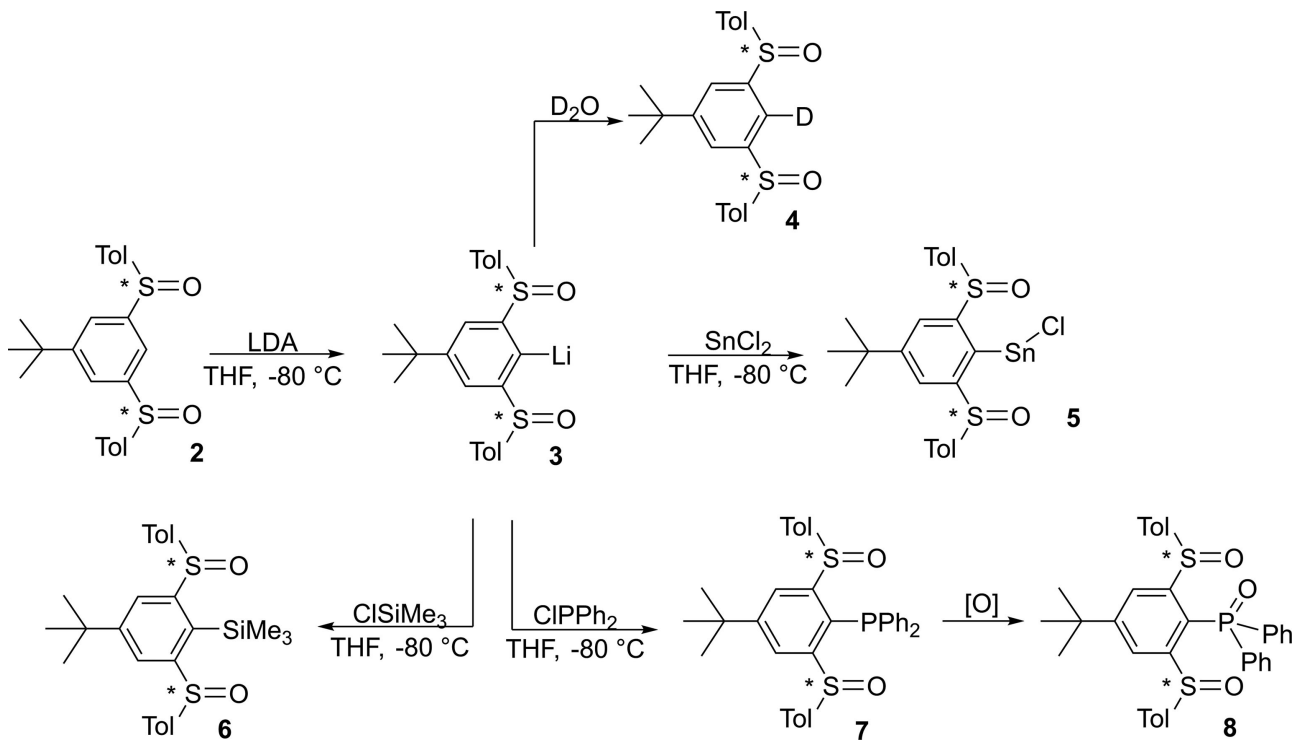

Scheme 2. Reactivity study of bis-sulfoxide $\mathbf{2}$.

pearance cannot be followed as clearly), as it can be seen on Figure S9 in ESI. The ${ }^{1} \mathrm{H}$ NMR spectrum for stannylene $\mathbf{5}$ shows 236 a downfield shift of the signals for the aromatic protons in the 7.27-7.85 ppm region. In the ${ }^{13} \mathrm{C}$ NMR spectrum of the stannylene 5 the signals situated at 169.7 and 170.1 ppm (in $\mathrm{CDCl}_{3}$ ) are characteristic for the ipso $\mathrm{C} 1$ atom of a group 14 metallylene. ${ }^{[40,42,59]}$

241 The formation of product 5 was also confirmed by the ${ }^{119} \mathrm{Sn}$ NMR with the appearance of a sharp signal at $75 \mathrm{ppm}$ and a broad one at $54 \mathrm{ppm}$. This is in agreement with the results previously observed in the case of the sulfone-sulfoxide stannylene, ${ }^{[43]}$ where signals were seen at 49.3 and $72.5 \mathrm{ppm}$. This

246 observation also suggests that coordination of the oxygen atoms of the sulfinyl groups is likely in compound 5, as it was proven for the sulfone-sulfoxide stannylene. ${ }^{[43]}$ The chemical shift for 5 observed at 75 and 50 ppm are downfield shifted compared to other O,C,O-chelating chlorostannylenes $251(-99 \mathrm{ppm}) .^{[60,61]}$ Furthermore, in the mass spectrum peaks for $\left[\mathrm{M}+\mathrm{CH}_{3} \mathrm{OH}\right]^{+}\left(\mathrm{C}_{24} \mathrm{H}_{26} \mathrm{O}_{2} \mathrm{~S}_{2} \mathrm{SnCl}+\mathrm{CH}_{3} \mathrm{OH}\right)$ at 597.0, $[\mathrm{M}-\mathrm{Cl}]$ $\left(\mathrm{C}_{24} \mathrm{H}_{25} \mathrm{O}_{2} \mathrm{~S}_{2} \mathrm{Sn}\right)$ at 529.0 and a dimeric species $\left[\mathrm{C}_{48} \mathrm{H}_{50} \mathrm{O}_{4} \mathrm{~S}_{4} \mathrm{Sn}\right]^{+}$ at 939.2 can be observed (See S11 ESI), species that suggest the existence of the stannylene in the mixture. However, due

256 to the sensitivity of the products, the mixture could not be separated and purified, thus further analysis was not realized.

For a better understanding of the chemical behaviour of bissulfoxide 2, reaction with trimethychlorosilane and chlorodiphenylphosphine, respectively was carried out. To the lithiated 261 bis-sulfoxide $\mathbf{3}$, obtained starting from a mixture of $d l$ and meso isomers of the bis-sulfoxide 2, a large excess of $\mathrm{Me}_{3} \mathrm{SiCl}$ was added. According to the ${ }^{1} \mathrm{H}$ NMR analysis of the reaction mixture, the expected compound bis-sulfoxide trimethylsilane [2,6(para-tolylsulfinyl)-4-tert-butyl-phenyl-trimethylsilane] $\mathbf{6}$ was

266 obtained in a mixture that was purified by column chromatography, using as mobile phase a mixture of ethyl acetate and cyclohexane (1:9). One of the two diastereomers of compound 6 was separated from this mixture; the other one was recovered as a mixture of the two diastereomers.
Single crystals suitable for X-ray analysis were separated from 271 a dichloromethane solution of the mixture of the two diastereomers of compound $\mathbf{6}$. The solid-state structure is presented in Figure 5 .

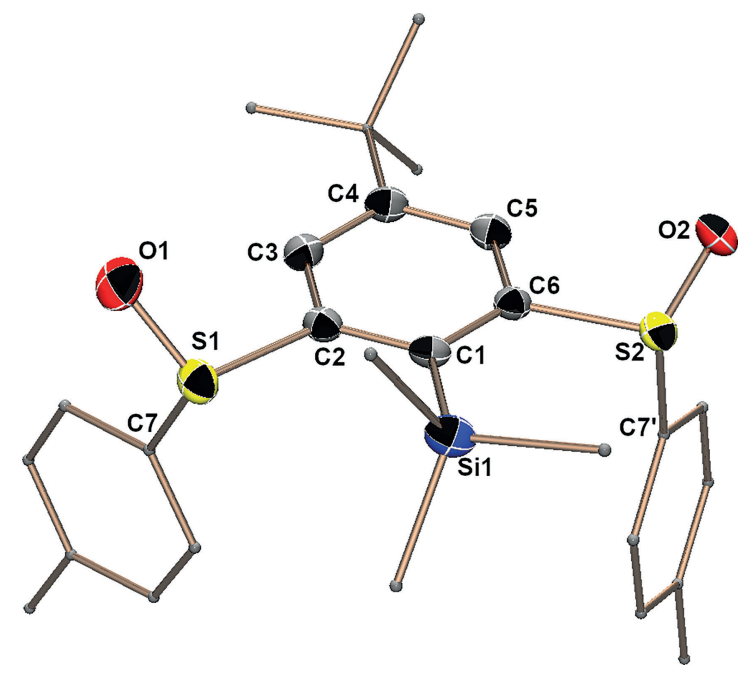

Figure 5. Molecular structure of compound 6 in the solid state $(50 \%$ probability level for the thermal ellipsoids). For clarity, the solvent molecules and hydrogen atoms are omitted; tolyl and tert-butyl groups are simplified. Selected bond lengths $[\AA]$ and bond angles [deg]: S1-O1 1.500(2); S2-O2 1.501(2), C1-Si1 1.926(2); O1-S1-C2 106.79(9), O2-S2-C6 106.18(9), C1-C2S1 121.25(14), C1-C6-S2 122.28(14), C6-C1-Si1 126.97(14), C2-C1-Si1 $119.75(14)$

Compound 6 crystallizes in a triclinic space group $(P \overline{1})$ with two molecules in the asymmetric unit. The solid state molecular 276 structure shows the meso diastereomer of the compound, the tolyl groups are positioned on the same side of the central aromatic ring. The oxygen atoms are positioned in a way that doesn't make possible interactions with the silicon atom. This is in contrast with related $\mathrm{Si}(\mathrm{IV})$ derivatives, supported by $\{2,6-281$ $\left.\left[\mathrm{P}(\mathrm{O})(\mathrm{OR})_{2}\right]_{2}-4-t \mathrm{BuC}_{6} \mathrm{H}_{2}\right\}$ ligands, ${ }^{[62]}$ where weak $\mathrm{O} \rightarrow$ Si coordinations were observed. 
In a reaction of $\mathbf{2}$ with chlorodiphenylphosphine the formation of the new compound $\mathbf{7}$ (bis-sulfoxide diphenyl phosphine) 286 was evidenced by multinuclear NMR spectroscopy. In the ${ }^{1} \mathrm{H}$ NMR spectra, the disappearance of the signals for $\mathrm{H} 1$ protons of the bis-sulfoxide $\mathbf{2}$ suggests the formation of compounds where the heteroatom is linked to the $\mathrm{C} 1$ carbon atom. In the ${ }^{31} \mathrm{P}$ NMR several signals can be observed in the -22 to $-8.6 \mathrm{ppm}$ 291 region, an upfield shift compared to the starting $\mathrm{CIPPh}_{2}$ from 81.8 ppm and characteristic for triaryl phosphines. ${ }^{[63]}$

The signal for the major compound is found at $-21.5 \mathrm{ppm}$ (71\%) and in the ${ }^{1} \mathrm{H}$ NMR signals corresponding to the bissulfoxide-diphenyl phosphine could be identified. From the so296 lution of this mixture in acetone, single crystals suitable for Xray diffraction were separated. The multinuclear NMR analysis of the separated crystals showed the signals corresponding to the two compounds. In the ${ }^{31} \mathrm{P}$ NMR a signal can be seen at -21.5 ppm (major signal, $71 \%$ ) for the bis-sulfoxide diphenyl

301 phosphine 7 and one at 31.8 ppm for the bis-sulfoxide diphenyl phosphine oxide 8 . In the ${ }^{1} \mathrm{H}$ NMR all the signals corresponding to these two compounds can be identified, signals characteristic to the $\mathrm{H} 3$ and $\mathrm{H} 5$ protons can be found at $8.20 \mathrm{ppm}(\mathrm{d}, 2 \mathrm{H}$, $\left.{ }^{3} J_{H H}=1.3 \mathrm{~Hz}\right)$ for compound 7 and at $8.35 \mathrm{ppm}\left(\mathrm{d},{ }^{3} \mathrm{~J}_{H H}=\right.$ $3062.6 \mathrm{~Hz}$ ) for compound $\mathbf{8}$, with the ratio already seen in the ${ }^{31} \mathrm{P}$ NMR, both downfield shifted compared to the bis-sulfoxide $\mathbf{2}$ (from 7.71 and 7.74 ppm).

In the mixture both the $-\mathrm{PPh}_{2} 7$ and $-\mathrm{P}(\mathrm{O}) \mathrm{Ph}_{2} 8$ derivatives are present, as a result of slow oxidation of the bis-sulfoxide

311 diphenyl phosphine. The single-crystal X-ray analysis showed the meso diastereomer, with the tolyl groups positioned on the same side of the central aromatic ring (Figure 6). The $\mathrm{P}-\mathrm{C}$ bond lengths $[1.839(4) \AA]$ are in agreement with values reported in literature. ${ }^{[64]}$

\section{Conclusion}

In conclusion, the new 1,3-(para-tolylsulfinyl)-5-tert-butyl-benzene 2, containing two sulfinyl groups in the ortho position of the central aromatic ring, was designed, synthesized and characterized. The synthesis of bis-sulfoxide $\mathbf{2}$ goes through the

321 new bis-thioether $\mathbf{1}$ which was also structurally completely characterized. The new bis-sulfoxide $\mathbf{2}$ was obtained as a mixture of $50-50 \%$ of the meso and $d l$ diastereomers, but the qualitative separation of the two diastereomers was possible using chiral column. The HPLC experiment proves that it is possible

326 to separate the $d l$ and the meso diastereomers, but also the $d$ and I-enantiomers.

Reactions of lithiated 1,3-(para-tolylsulfinyl)-5-tert-butylbenzene $\mathbf{2}$ with trimethychlorosilane and chlorodiphenylphosphine showed that deprotonation at the $\mathrm{H} 1$ of the bis-sulfoxide

3312 and reactions with $p$ block elements are possible. Furthermore, the bis-sulfoxide $\mathbf{2}$ was tested with the purpose to function as pincer ligand in the stabilization of divalent group 14 elements, thus a new stannylene was evidenced. However, due to the use of the bis-sulfoxide as a mixture of the two diastereo-

336 mers $d l$ and meso in the reactions, a mixture of isomers of the products was obtained as well.

The results presented here suggest that the newly obtained sulfinyl based compounds can be employed as ligands for the

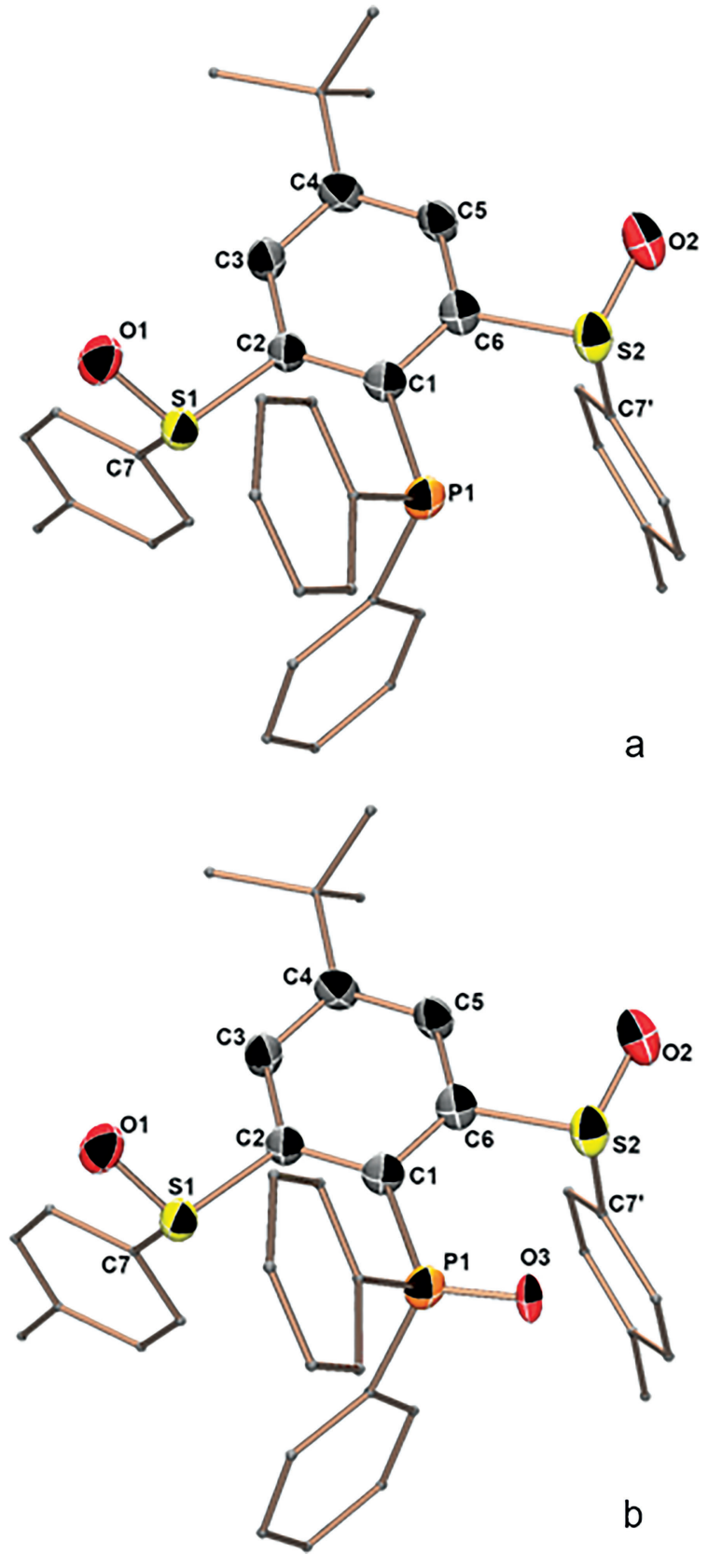

Figure 6. Molecular structure of compounds 7 (a) and 8 (b) in the solid state ( $50 \%$ probability level for the thermal ellipsoids). For clarity, the solvent molecules and hydrogen atoms are omitted; tolyl, tert-butyl and phenyl groups are simplified. Selected bond lengths $[\AA ̊]$ and bond angles [deg]: S1-O1 1.490(3); S2-O2 1.485(4), C1-P1 1.839(4), P1-O3 (for 8) 1.369(11); O1-S1-C2 105.95(18), O2-S2-C6 104.7(2), C1-C2-S1 120.6(3), C1-C6-S2 121.8(3), C6C1-P1 117.0(3), C2-C1-P1 127.3(3).

stabilization of the organic compounds of the heavy $p$ block elements.

\section{Experimental Section}

\section{Materials and Methods}

All manipulations were performed in a dry, oxygen-free atmosphere of argon by using standard Schlenk-line and glove-box techniques. 
346 The solvents were purified using MBRAUN SBS-800 purification system.

The NMR spectra were recorded with a Bruker Avance II $300 \mathrm{MHz}$ apparatus, Bruker Avance $400 \mathrm{MHz}$ apparatus and Bruker Avance $600 \mathrm{MHz}$ apparatus using the following internal or external referen-

351 ces: TMS for ${ }^{1} \mathrm{H},{ }^{13} \mathrm{C}\left\{{ }^{1} \mathrm{H}\right\}$ and ${ }^{29} \mathrm{Si} N M R$, SnMe4 for ${ }^{119} \mathrm{Sn}, \mathrm{H}_{3} \mathrm{PO}_{4}$ for ${ }^{31} \mathrm{P}$ NMR. Chemical shifts are expressed in parts per million (ppm). The NMR assignments were confirmed by COSY $\left({ }^{1} \mathrm{H}-{ }^{1} \mathrm{H}\right), \mathrm{HSQC}\left({ }^{1} \mathrm{H}-\right.$ $\left.{ }^{13} \mathrm{C}\right)$, and HMBC $\left({ }^{1} \mathrm{H}_{-}{ }^{13} \mathrm{C}\right)$ experiments. Mass spectrometry (MS) spectra were measured with a Hewlett-Packard 5989A in the electron

356 impact mode (70 eV). High-resolution mass spectrometry (HRMS) spectra were measured with a GCT Premier Waters in DCl mode $\left(\mathrm{CH}_{4}\right)$. Melting points were measured in a sealed capillary using the Stuart automatic melting point SMP40 apparatus.

The X-ray data were collected at 193(2) K on a Bruker - AXS APEX II

361 Quazar diffractometer, equipped with a $30 \mathrm{~W}$ air-cooled microfocus source using Mo- $K_{\alpha}$ radiation $(\lambda=0.71073 \AA$ ). Phi- and omega-scans were used. The data were integrated with SAINT and an empirical absorption correction with SADABS was applied. The structures were solved by direct methods using SHELXS-97 and refined using

366 a least-squares method on $F^{2}$. All non- $\mathrm{H}$ atoms were refined with anisotropic displacement parameters. ${ }^{[65-68]}$ For $\mathbf{7}$ and 8, tied-occupancy refinement confirmed that in the crystal two compounds crystallized together at a single site in the same unit cell, one containing the atom $\mathrm{O} 3$ with an occupancy of 0.27 .

371 Deposition Numbers 2019650, 2019651, 2019652, 2019653 contain the supplementary crystallographic data for this paper. These data are provided free of charge by the joint Cambridge Crystallographic Data Centre and Fachinformationszentrum Karlsruhe Access Structures service www.ccdc.cam.ac.uk/structures.

\section{Computational Details}

Theoretical calculations were performed within the framework of the Density Functional Theory (DFT), using the Gaussian 09 software. ${ }^{[68]}$ Molecular geometries were fully optimized without any symmetry constrains in THF using the SMD variation of the polariza-

381 ble continuum solvation model ${ }^{[69]}$ (for TetraHydroFuran, $\varepsilon=7.4257$ ). The $\mathrm{PBEO}^{[70]}$ hybrid functional and the valence triple-zeta Def2$T_{Z V P}{ }^{[71]}$ basis set were employed in all calculations. The optimization criteria were set to tight while the integration grid used within the calculations was of 99 radial shells and 950 angular points for

386 each shell $(99,950)$, known as the "ultrafine" grid in Gaussian 09. Calculations of the vibrational frequencies were performed in order to characterize the nature of the stationary points. Additionally, vibrational analyses were used to compute enthalpies within the framework of the harmonic approximation for vibrational contribu-

391 tion (further details on the thermodynamic equations are available in Ref. $\left.{ }^{[72]}\right)$. Noteworthy, all reported energies throughout this study (relative energies between isomers, activation barriers, etc.) contain the thermal enthalpy corrections to the DFT energy.

Synthesis of Bis-thioether 1 [1,3-(para-Tolyl sulfide)-5-tert396 butyl-benzene] (1): A mixture of $\mathrm{Pd}_{2} \mathrm{dba}_{3}(784 \mathrm{mg}, 0.086 \mathrm{mmol}$, $5 \mathrm{~mol}-\%$ ) and Xantphos (991 mg, $1.71 \mathrm{mmol}, 10 \mathrm{~mol}-\%$ ) in $5 \mathrm{~mL}$ of toluene was stirred for 5 minutes, then $p$-toluenethiol $(6.380 \mathrm{~g}$, $51.40 \mathrm{mmol}, 3$ equiv.), of 1,3-dibromo-5-tert-butylbenzene $(5 \mathrm{~g}$, $0.017 \mathrm{mmol}, 1$ equiv.), a $\mathrm{KOH}$ solution $(50.9 \mathrm{~mL}, 50 \%$ aqueous solu-

401 tion) and $80 \mathrm{~mL}$ of toluene were added. The biphasic system was heated to $90{ }^{\circ} \mathrm{C}$ for $48 \mathrm{~h}$. After cooling to room temperature, $75 \mathrm{~mL}$ of $\mathrm{CH}_{2} \mathrm{Cl}_{2}$ was added and the layers separated. The aqueous phase was washed with $75 \mathrm{~mL}$ of $\mathrm{CH}_{2} \mathrm{Cl}_{2}$, then all organic phases were washed with a saturated $\mathrm{NaCl}$ solution then dried on $\mathrm{Na}_{2} \mathrm{SO}_{4}$. After 406 evaporating all solvents, red oil remained. The obtained bis-thio- ether was purified by column chromatography (cyclohexane) (6.18 g, yield $=95 \%) .{ }^{1} \mathrm{H}$ NMR $\left(\mathrm{CDCl}_{3}\right) \delta=1.23(\mathrm{~s}, 9 \mathrm{H}, t \mathrm{Bu}), 2.35(\mathrm{~s}$, $6 \mathrm{H}, \mathrm{Me}), 6.82\left(\mathrm{t}, 1 \mathrm{H},{ }^{4} \mathrm{~J}_{H H}=1.6 \mathrm{~Hz}, \mathrm{CH} \mathrm{Ph}\right), 7.10\left(\mathrm{~d}, 4 \mathrm{H},{ }^{3} \mathrm{~J}_{H H}=7.9 \mathrm{~Hz}\right.$, $m-C H$ Tol), $7.14\left(\mathrm{~d}, 2 \mathrm{H},{ }^{4} \mathrm{~J}_{H H}=1.7 \mathrm{~Hz}, m-\mathrm{CH} \mathrm{Ph}\right), 7.24\left(\mathrm{~d}, 4 \mathrm{H},{ }^{3} \mathrm{~J}_{H H}=\right.$ $7.6 \mathrm{~Hz}, \mathrm{o}-\mathrm{CH}$ Tol). ${ }^{13} \mathrm{C}$ NMR $\left(\mathrm{CDCl}_{3}\right) \delta=21.3(\mathrm{Me}), 31.2\left[\mathrm{C}\left(\mathrm{CH}_{3}\right)_{3}\right], 35.0411$ $\left[\mathrm{C}\left(\mathrm{CH}_{3}\right)_{3}\right], 124.6,126.9,130.1,130.7,132.5,137.8,137.9,152.8$. M.p. 75-76 ${ }^{\circ} \mathrm{C}$. MS ( $\left.\mathrm{DCl} \mathrm{NH} \mathrm{N}_{3}\right)\left(\mathrm{C}_{24} \mathrm{H}_{26} \mathrm{~S}_{2}\right)[\mathrm{M}+1]^{+}$379.1. Elemental analysis calculated for $\mathrm{C}_{24} \mathrm{H}_{26} \mathrm{~S}_{2}$ : C 76.14; $\mathrm{H} 6.92$; found $\mathrm{C} 76.21 ; \mathrm{H} 6.61$.

Synthesis of Bis-sulfoxide 2 [1,3-(para-tolylsulfinyl)-5-tert-butyl-

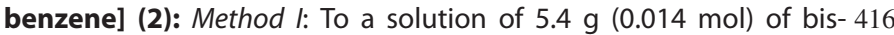
thioether 1 in $32 \mathrm{~mL}$ of glacial acetic acid, a solution of $2.6 \mathrm{~mL}$ of $\mathrm{H}_{2} \mathrm{O}_{2}$ (33wt.-\%, $0.028 \mathrm{mmol}, 2$ equiv.) in $18 \mathrm{~mL}$ of glacial acetic acid was added dropwise. The mixture was stirred at room temperature for 48 hours, while a clear solution was obtained. A saturated solution of $\mathrm{KOH}$ was added to the reaction mixture until a neutral $\mathrm{pH} 421$ was obtained. Then $25 \mathrm{~mL}$ of $\mathrm{CH}_{2} \mathrm{Cl}_{2}$ were added and the layers were separated. The aqueous layer was extracted six times with $25 \mathrm{~mL}$ of $\mathrm{CH}_{2} \mathrm{Cl}_{2}$, the organic layers were united and washed twice with $50 \mathrm{~mL}$ of aqueous saturated $\mathrm{NaCl}$ solution then dried on $\mathrm{Na}_{2} \mathrm{SO}_{4}$. After evaporating the solvent, a white sticky solid was ob- 426 tained. The bis-sulfoxide $\mathbf{2}$ was separated from the mixture by column chromatography (cyclohexane/ethyl acetate, 8:2). It was obtained as a white powder a mixture of $50-50 \%$ of the meso and $d l$ diastereomers ( $3.4 \mathrm{~g}, 58 \%$ yield). The $d l$ isomer could be separated by fractional crystallization from acetone. Transparent crystals were 431 obtained of the $d l$ diastereomer.

Method II: To a solution of bis-thioether $1(3 \mathrm{~g}, 7.9 \mathrm{mmol})$ in $50 \mathrm{~mL}$ of $\mathrm{CH}_{2} \mathrm{Cl}_{2}$ a solution of $m$ CPBA $(4.5 \mathrm{~g}, 26.2 \mathrm{mmol}, 3$ equiv.) in $50 \mathrm{~mL}$ of $\mathrm{CH}_{2} \mathrm{Cl}_{2}$ was added dropwise at $0{ }^{\circ} \mathrm{C}$. The mixture was stirred at $0{ }^{\circ} \mathrm{C}$ for one hour and at room temperature for 20 minutes then 436 washed three times with $75 \mathrm{~mL}$ of an aqueous saturated solution of $\mathrm{NaHCO}_{3}$ and all solvents evaporated. The bis-sulfoxide $\mathbf{2}$ was separated by column chromatography (cyclohexane/ethyl acetate, $8: 2)$ as the mixture of the meso and $d /$ diastereomers (0.8 g, $25 \%$ yield). ${ }^{1} \mathrm{H}$ NMR $\left(\mathrm{CDCl}_{3}\right) d l$ isomer: $\delta=1.29(\mathrm{~s}, 9 \mathrm{H}, t \mathrm{Bu}), 2.36(\mathrm{~s}, 6 \mathrm{H}, 441$ Me), $7.23\left(\mathrm{~d}, 4 \mathrm{H},{ }^{3} \mathrm{~J}_{H H}=7.9 \mathrm{~Hz}, m-\mathrm{CH}\right.$ Tol), $7.45\left(\mathrm{~d}, 4 \mathrm{H},{ }^{3} \mathrm{~J}_{H H}=8.2 \mathrm{~Hz}\right.$, o-CH Tol), $7.50\left(\mathrm{t}, 1 \mathrm{H},{ }^{4} \mathrm{~J}_{H H}=1.6 \mathrm{~Hz}, H 1 \mathrm{Ph}\right), 7.74\left(\mathrm{~d}, 2 \mathrm{H},{ }^{4} \mathrm{~J}_{H H}=1.6 \mathrm{~Hz}\right.$, $m$ - $\mathrm{CH}$ Ph). meso isomer: $\delta=1.28(\mathrm{~s}, 9 \mathrm{H}, t \mathrm{Bu}), 2.37(\mathrm{~s}, 6 \mathrm{H}, \mathrm{Me}), 7.25$ $\left(\mathrm{d}, 4 \mathrm{H},{ }^{3} \mathrm{~J}_{H H}=7.9 \mathrm{~Hz}, m-\mathrm{CH}\right.$ Tol$), 7.48\left(\mathrm{~d}, 4 \mathrm{H},{ }^{3} \mathrm{~J}_{H H}=8.2 \mathrm{~Hz}, \mathrm{o}-\mathrm{CH}\right.$ Tol$)$, $7.58\left(\mathrm{t}, 1 \mathrm{H},{ }^{4} J_{H H}=1.6 \mathrm{~Hz}, \mathrm{H} 1 \mathrm{Ph}\right), 7.71\left(\mathrm{~d}, 2 \mathrm{H},{ }^{4} J_{H H}=1.6 \mathrm{~Hz}, m-C H 446\right.$ $\mathrm{Ph}) .{ }^{13} \mathrm{C}$ NMR $\left(\mathrm{CDCl}_{3}\right)$ meso isomer $\delta=21.6(\mathrm{Me}), 31.2(t \mathrm{Bu}), 35.8(\mathrm{C}$ tBu), $118.3(\mathrm{C} 1)$, , 123.8 (C3, C5), 125.1 (C8, C12), 130.3 (C9, C11), 142.0 and $142.2(C 7, C 10), 147.3(C 2, C 6), 154.5(C 4) . d l$ isomer $\delta=$ $21.6(\mathrm{Me}), 31.2(t \mathrm{Bu}), 35.7(\mathrm{C} t \mathrm{Bu}), 118.4(\mathrm{C} 1), 123.7(\mathrm{C} 3, \mathrm{C} 5), 125.2$ (C8, C12), 130.3 (C9, C11), 142.0 and 142.1 (C7, C10), 147.3 (C2, C6), 451 154.6 (C4). MS (DCl CH $\left.{ }_{4}\right)\left(\mathrm{C}_{24} \mathrm{H}_{26} \mathrm{O}_{2} \mathrm{~S}_{2}\right)[\mathrm{M}+1]^{+} 411.1439$.

The separation of the two diastereomers of bis-sulfoxide $\mathbf{2}$ was shown by an HPLC experiment with an Agilent HPLC 1200 instrument on a chiral column $[(R, R)$-Whelk-O 1Pirkle-type Chiral Column] at $30{ }^{\circ} \mathrm{C}$ using as mobile phase a mixture of hexane/2-propanol -456 dichloromethane in the ratio 85:14:1.

Synthesis of Compounds 3 and 4: Method $I$ : To a solution of $300 \mathrm{mg}$ of bis-sulfoxide $2(0.73 \mathrm{mmol})$ in $12 \mathrm{~mL}$ of THF cooled to $-80{ }^{\circ} \mathrm{C}$, a freshly prepared LDA solution in THF $(0.80 \mathrm{mmol}, 10 \%$ excess) was added. The dark orange solution was stirred at this 461 temperature for 30 minutes then warmed up to $-40{ }^{\circ} \mathrm{C}$ and stirred for another 30 minutes.

Method II: To a solution of $100 \mathrm{mg}$ of bis-sulfoxide $2(0.73 \mathrm{mmol})$ in $12 \mathrm{~mL}$ of THF (or toluene) cooled to $-80{ }^{\circ} \mathrm{C}$, a solution of LDA (prepared previously and kept as solid in the glovebox) in THF (or 466 toluene) $(0.80 \mathrm{mmol}, 10 \%$ excess) was added. The dark orange solu- 
tion was stirred at this temperature for 30 minutes then warmed up to $-40{ }^{\circ} \mathrm{C}$ and stirred for another 30 minutes.

To the solution of the lithiated compound $3 \mathrm{D}_{2} \mathrm{O}(1 \mathrm{~mL})$ was added

471 then stirred for 5 minutes at room temperature to obtain a light yellow solution. Solvents were evaporated and compound $\mathbf{4}$ was obtained as a white solid.

Synthesis of Bis-sulfoxide Stannylene [2,6-(para-tolylsulfinyl)-4tert-butyl-phenyl-chlorostannylene] (5): The freshly prepared so-

476 lution of the lithiated bis-sulfoxide 3 [prepared from $100 \mathrm{mg}$ of bissulfoxide $2(0.73 \mathrm{mmol})]$ was added to a solution of $\mathrm{SnCl}_{2}(138.6 \mathrm{mg}$, $0.73 \mathrm{mmol}, 1$ equiv.) in $2 \mathrm{~mL}$ of THF (or toluene) at $-40{ }^{\circ} \mathrm{C}$. The yellow mixture was stirred in the cooling bath for one hour then at room temperature for another hour. Solvents were evaporated; the

481 solid was extracted with $\mathrm{CH}_{2} \mathrm{Cl}_{2}$. A white solid was obtained as a mixture of compounds. ${ }^{1} \mathrm{H}$ NMR $\left(\mathrm{CDCl}_{3}\right) \delta=1.13-1.16(t \mathrm{Bu}), 2.35-$ 2.37 (Me), 7.27-7.30 (CH Tol), $7.34(\mathrm{CH} \mathrm{Tol} / \mathrm{Ph}), 7.69\left(\mathrm{~d},{ }^{3} \mathrm{~J}_{H H}=8.1 \mathrm{~Hz}\right.$, $\mathrm{CH}$ Tol/Ph), $7.83\left(\mathrm{~d},{ }^{3} \mathrm{~J}_{\mathrm{HH}}=8.1 \mathrm{~Hz}, m-\mathrm{CH}\right.$ Tol). ${ }^{13} \mathrm{C} \mathrm{NMR}\left(\mathrm{CDCl}_{3}\right) \delta=$ 21.6, $21.7(\mathrm{Me}), 31.1(\mathrm{tBu}), 35.3(\mathrm{C} t \mathrm{Bu}), 118.3-153.9$ many signals, 486169.7 and 170.1 (C1). ${ }^{119} \mathrm{Sn}\left(\mathrm{CDCl}_{3}\right) \delta=75.1$ (sharp); 54 (broad). MS (MS ESI+) $\left(\mathrm{C}_{24} \mathrm{H}_{25} \mathrm{ClSnO}_{2} \mathrm{~S}_{2}\right):\left[\mathrm{M}+\mathrm{CH}_{3} \mathrm{OH}\right]^{+}\left(\mathrm{C}_{24} \mathrm{H}_{26} \mathrm{O}_{2} \mathrm{~S}_{2} \mathrm{SnCl}+\right.$ $\left.\mathrm{CH}_{3} \mathrm{OH}\right)$ at 597.0, [M - Cl] $\left(\mathrm{C}_{24} \mathrm{H}_{25} \mathrm{O}_{2} \mathrm{~S}_{2} \mathrm{Sn}\right)$ at 529.0, $\left[\mathrm{C}_{48} \mathrm{H}_{50} \mathrm{O}_{4} \mathrm{~S}_{4} \mathrm{Sn}\right]^{+}$ at 939.2 .

Synthesis of Bis-sulfoxide Trimethylsilane [2,6-(para-Tolyl-

491 sulfinyl)-4-tert-butyl-phenyl-trimethylsilane] (6): To a solution of $100 \mathrm{mg}$ of bis-sulfoxide $2(0.24 \mathrm{mmol})$ in $4 \mathrm{~mL}$ of THF cooled to $-80{ }^{\circ} \mathrm{C}$ a freshly prepared LDA solution in THF $(0.27 \mathrm{mmol}, 10 \%$ excess) was added dropwise. The orange solution was stirred at this temperature for 30 minutes, then a large excess of trimethychloro-

496 silane $(0.5 \mathrm{~mL})$ was added. After stirring at room temperature overnight, volatiles were evaporated and the product was purified by column chromatography (ethyl acetate:cyclohexane 2:8) (76 mg, $64 \%$ yield). Transparent crystals of 6 were obtained in $\mathrm{CH}_{2} \mathrm{Cl}_{2}$. meso diastereomer ${ }^{1} \mathrm{H}$ NMR $\left(\mathrm{CDCl}_{3}\right) \delta=0.54\left(\mathrm{~s}, 9 \mathrm{H}, \mathrm{Me}_{3} \mathrm{Si}\right), 1.21(\mathrm{~s}, 9 \mathrm{H}$,

$501 \mathrm{tBu}), 2.38(\mathrm{~s}, 6 \mathrm{H}, \mathrm{Me}), 7.19\left(\mathrm{~s}, 8 \mathrm{H}, J_{\mathrm{Si}-\mathrm{H}}=9.0 \mathrm{~Hz}, o_{-}\right.$and $\left.m-\mathrm{CH} \mathrm{Tol}\right)$, $8.05(\mathrm{~s}, 2 \mathrm{H}, \mathrm{m}-\mathrm{CH} \mathrm{Ph}) .{ }^{13} \mathrm{C} \mathrm{NMR}\left(\mathrm{CDCl}_{3}\right) \delta=4.8\left(\mathrm{SiMe}_{3}\right), 21.5(\mathrm{Me})$, $30.8(t \mathrm{Bu}), 35.7$ (C tBu), 125.5 (C8, C12), 125.8 (C3, C5), 130.0 (C9, C11), 135.7 (C1), 141.2 (C10), 143.2 (C7), 153.5 (C2, C6), 155.6 (C4). ${ }^{29} \mathrm{Si} \mathrm{NMR}\left(\mathrm{CDCl}_{3}\right) \delta=-2.18$. dl diastereomer ${ }^{1} \mathrm{H} \mathrm{NMR}\left(\mathrm{CDCl}_{3}\right) \delta=$ $5060.59\left(\mathrm{~s}, 9 \mathrm{H}, \mathrm{Me}_{3} \mathrm{Si}\right), 1.11(\mathrm{~s}, 9 \mathrm{H}, t \mathrm{Bu}), 2.36(\mathrm{~s}, 6 \mathrm{H}, \mathrm{Me}), 7.25(\mathrm{~d}, 4 \mathrm{H}$, $\left.{ }^{3} \mathrm{~J}_{\mathrm{HH}}=8.1 \mathrm{~Hz}, m-\mathrm{CH} \mathrm{Tol}\right), 7.31\left(\mathrm{~d}, 4 \mathrm{H},{ }^{3} \mathrm{~J}_{\mathrm{HH}}=8.4 \mathrm{~Hz}, \mathrm{o}-\mathrm{CH} \mathrm{Tol}\right), 7.90$ $(\mathrm{s}, 2 \mathrm{H}, \mathrm{m}-\mathrm{CH} \mathrm{Ph}) .{ }^{29} \mathrm{Si} \mathrm{NMR}\left(\mathrm{CDCl}_{3}\right) \delta=-1.85$. MS (MS ESI+) $\left(\mathrm{C}_{27} \mathrm{H}_{34} \mathrm{O}_{2} \mathrm{~S} 2 \mathrm{Si}\right.$ ) $[\mathrm{M}+1]^{+} 483.1858$ (calculated for $\mathrm{C}_{27} \mathrm{H}_{35} \mathrm{O}_{2} \mathrm{~S}_{2} \mathrm{Si}$ 483.1848).

511 Synthesis of Bis-sulfoxide-diphenylphospine 7 [2,6-(para-Tolylsulfinyl)-4-tert-butyl-phenyl-diphenylphosphine]: To a solution of $200 \mathrm{mg}$ of bis-sulfoxide $2(0.49 \mathrm{mmol})$ in $6 \mathrm{~mL}$ of THF cooled to $-80{ }^{\circ} \mathrm{C}$, a solution of $103.4 \mathrm{mg}$ of LDA ( $0.54 \mathrm{mmol}, 1.1$ equiv.) in $2 \mathrm{~mL}$ of THF was added at $-80^{\circ} \mathrm{C}$. After stirring the mixture for 30

516 minutes at this temperature, $0.12 \mathrm{~mL}$ of chlorodiphenylphosphine ( $0.66 \mathrm{mmol}, 1.35$ equiv.) was added. The mixture was stirred at room temperature overnight and volatiles were evaporated to obtain a yellow solid as a mixture of two diastereomers. Transparent crystals were separated in acetone.

521 Compound 7: ${ }^{1} \mathrm{H}$ NMR $\left(\mathrm{CDCl}_{3}\right) \delta=1.35(\mathrm{~s}, 9 \mathrm{H}, t \mathrm{Bu}), 2.31(\mathrm{~s}, 6 \mathrm{H}, \mathrm{Me})$, $7.06\left(\mathrm{~s}, 8 \mathrm{H}, o^{-}\right.$and $\mathrm{m}-\mathrm{CH}$ Tol), 7.04-7.24 and 7.36-7.57 $\left(\mathrm{m}, \mathrm{PPh}_{2}\right)$, $8.20\left(\mathrm{~d}, 2 \mathrm{H}, \mathrm{H} 3\right.$ and $\left.\mathrm{H} 5,{ }^{3} \mathrm{~J}_{\mathrm{HH}}=1.3 \mathrm{~Hz}\right) .{ }^{13} \mathrm{C} \mathrm{NMR}\left(\mathrm{CDCl}_{3}\right) \delta=21.5$ (Me), $31.0(t \mathrm{Bu}), 36.2(\mathrm{CtBu}), 125.9\left(\mathrm{CH} \mathrm{PPh}_{2}\right), 126.6\left(\mathrm{~d},{ }^{3} J_{P H}=2.3 \mathrm{~Hz}\right.$, C3, C5), $128.8\left(\mathrm{~m}, \mathrm{CH} \mathrm{PPh}_{2}\right), 129.8(\mathrm{CH}$ Tol$), 132.3\left(\mathrm{~d}, J_{P H}=17.9 \mathrm{~Hz}\right.$,

$526 \mathrm{CH}$ Tol), $132.8\left(\mathrm{~d}, J_{\mathrm{PH}}=2.8 \mathrm{~Hz}, \mathrm{CH} \mathrm{PPh}_{2}\right), 133.8\left(\mathrm{~d}, J_{P H}=11.0 \mathrm{~Hz}\right)$ 141.0. 141.3, 142.2, 143.0, 152.7 and $154.1\left(\mathrm{~d}, J_{P H}=14.6 \mathrm{~Hz}\right)$ for $\mathrm{C} 1$, $\mathrm{C} 2, \mathrm{C} 6, \mathrm{C} 7, \mathrm{C} 10$ and $\mathrm{PPh}_{2}$, ipso $157.8(\mathrm{C} 4) .{ }^{31} \mathrm{P}$ NMR $\left(\mathrm{CDCl}_{3}\right) \delta=-21.5$.
MS (MS ESI+) $\left(\mathrm{C}_{36} \mathrm{H}_{35} \mathrm{O}_{2} \mathrm{PS}_{2}\right)[\mathrm{M}+1]^{+} 595.1907$ (calculated for $\mathrm{C}_{36} \mathrm{H}_{36} \mathrm{O}_{2} \mathrm{PS}_{2}$ 595.1895).

Compound 8 (Bis-sulfoxide-diphenylphospine oxide): ${ }^{1} \mathrm{H}$ NMR 531 $\left(\mathrm{CDCl}_{3}\right) \delta=1.32(\mathrm{~s}, t \mathrm{Bu}), 2.33(\mathrm{~s}, \mathrm{Me}), 7.06(\mathrm{~s}, 8 \mathrm{H}), 7.04-7.24$ and 7.36-7.57 ( $m, o-$ and $m-\mathrm{CH}$ Tol, $\left.\mathrm{PPh}_{2}\right), 8.35\left(\mathrm{~d}, \mathrm{H} 3\right.$ and $\mathrm{H} 5,{ }^{3} \mathrm{~J}_{H H}=$ 2.6). ${ }^{13} \mathrm{C}$ NMR $\left(\mathrm{CDCl}_{3}\right) \delta=30.8(t \mathrm{Bu}), 125.5(\mathrm{C} 8, \mathrm{C} 12), 126.7(\mathrm{C} 3, \mathrm{C} 5)$, $129.1\left(\mathrm{~d}, J_{P H}=12.6 \mathrm{~Hz}, \mathrm{CH} \mathrm{PPh}_{2}\right), 129.7\left(\mathrm{CH}\right.$ Tol), $132.4\left(\mathrm{~d}, J_{P H}=\right.$ $10.6 \mathrm{~Hz}, \mathrm{CH}$ Tol), 159.0 (C4). ${ }^{31} \mathrm{P}$ NMR $\left(\mathrm{CDCl}_{3}\right) \delta=31.8$. MS (MS ESI+) 536 $\left(\mathrm{C}_{36} \mathrm{H}_{35} \mathrm{O}_{3} \mathrm{PS}_{2}\right)[\mathrm{M}+1]^{+} 611.1857$.

\section{Acknowledgments}

This work was supported by a grant of Ministry of Research and Innovation, CNCS-UEFISCDI, project number PN-III-P4-ID-PCE2016-0351, within PNCDI III, by the Centre National de la Re- 541 cherche Scientifique (CNRS), the Université de Toulouse (UPS) and by the Babeș-Bolyai University of Cluj-Napoca. The authors thank Prof. Monica Toşa for the help with the HPLC experiment realized on the chiral column.

Keywords: Bis-sulfoxide - Stannylene - Silicon - P block element · Phosphorus

[1] a) V. Snieckus, Chem. Rev. 1990, 90, 879-933; b) D. Kaiser, I. Klose, R. Oost, J. Neuhaus, N. Maulide, Chem. Rev. 2019, 119, 8701-8780; c) E. Wojaczyńska, J. Wojaczyński, Chem. Rev. 2020, 120, 4578-4611.

[2] J. P. Flemming, M. B. Berry, J. M. Brown, Org. Biomol. Chem. 2008, 6, 551 1215-1221.

[3] I. Fernández, N. Khiar, Chem. Rev. 2003, 103, 3651-3706.

[4] E. Wojaczyńska, J. Wojaczyński, Chem. Rev. 2010, 110, 4303-4356.

[5] G. Sipos, E. E. Drinkel, R. Dorta, Chem. Soc. Rev. 2015, 44, 3834-3860.

[6] S. Otocka, M. Kwiatkowska, L. Madalińska, P. Kiełbasiński, Chem. Rev. 556 2017, 117, 4147-4181.

[7] E. M. Stang, M. C. White, Nat. Chem. 2009, 1, 547-551.

[8] S. E. Ammann, G. T. Rice, M. C. White, J. Am. Chem. Soc. 2014, 136, 1083410837.

[9] J. Mikšátko, V. Eigner, H. Dvořáková, P. Lhoták, Tetrahedron Lett. 2016, 57, 561 3781-3784.

[10] Z. Xu, H. Liu, M. H. Mahmood, Y. Cai, X. Xu, Y. Tang, CrystEngComm 2014, 16, 3839-3842.

[11] D. Madec, F. Mingoia, C. Macovei, G. Maitro, G. Giambastiani, G. Poli, Eur. J. Org. Chem. 2005, 552-557.

[12] F. García-Flores, L. S. Flores-Michel, E. Juaristi, Tetrahedron Lett. 2006, 47, 8235-8238.

[13] X. H. Bu, W. Chen, S. L. Lu, R. H. Zhang, D. Z. Liao, W. M. Bu, M. Shionoya, F. Brisse, J. Ribas, Angew. Chem. Int. Ed. 2001, 40, 3201-3203; Angew. Chem. 2001, 113, 3301.

[14] J. R. Li, X. H. Bu, Eur. J. Inorg. Chem. 2008, 27-40.

[15] R. M. Mallorquin, S. Chelli, F. Brebion, L. Fensterbank, J. P. Goddard, M. Malacria, Tetrahedron: Asymmetry 2010, 21, 1695-1700.

[16] P. K. Dornan, P. L. Leung, V. M. Dong, Tetrahedron 2011, 67, 4378-4384.

[17] H. Katagiri, S. Tanaka, K. Ohkubo, Y. Akahira, N. Morohashi, N. Iki, T. Hat- 576 tori, S. Miyano, RSC Adv. 2014, 4, 9608-9616.

[18] E. E. Drinkel, L. Wu, A. Linden, R. Dorta, Organometallics 2014, 33, 627636.

[19] D. L. M. Suess, J. C. Peters, Organometallics 2012, 31, 5213-5222.

[20] D. R. Evans, M. Huang, W. M. Seganish, J. C. Fettinger, T. L. Williams, Inorg. 581 Chem. Commun. 2003, 6, 462-465.

[21] D. R. Evans, M. Huang, W. M. Seganish, J. C. Fettinger, T. L. Williams, Organometallics 2002, 21, 893-900.

[22] T. Schaub, U. Radius, Y. Diskin-Posner, G. Leitus, L. J. W. Shimon, D. Milstein, Organometallics 2008, 27, 1892-1901.

[23] H. Locke, A. Herrera, F. W. Heinemann, A. Linden, S. Frieß, B. Schmid, R. Dorta, Organometallics 2015, 34, 1925-1931. 
[24] M. C. Carreno, J. L. Garcia Ruano, A. M. Martin, C. Pedregal, J. H. Rodriguez, A. Rubio, J. Sanchez, G. Solladie, J. Org. Chem. 1990, 55, 21205912128.

[25] R. Bikas, H. Hosseini-Monfared, J. Sanchiz, M. Siczek, T. Lis, RSC Adv. 2014, 4, 36175-36182.

[26] C. Redshaw, L. Clowes, D. L. Hughes, M. R. J. Elsegood, T. Yamato, Organometallics 2011, 30, 5620-5624.

596 [27] C. Caupène, C. Boudou, S. Perrio, P. Metzner, J. Org. Chem. 2005, 70, 2812-2815.

[28] G. Maitro, G. Prestat, D. Madec, G. Poli, J. Org. Chem. 2006, 71, 74497454.

6015954.

[30] G. Maitro, S. Vogel, M. Sadaoui, G. Prestat, D. Madec, G. Poli, Org. Lett. 2007, 9, 5493-5496.

[31] J. Wang, M. Wang, P. Cao, L. Jiang, G. Chen, J. Liao, Angew. Chem. Int. Ed. 2014, 53, 6673-6677; Angew. Chem. 2014, 126, 6791.

606 [32] K. Ogura, M. Suzuki, G. Tsuchihashi, Bull. Chem. Soc. Jpn. 1980, 53, 14141416.

[33] R. P. Greenhalgh, Synlett 1992, 235-236.

[34] J. Skarzewski, E. Ostrycharz, R. Siedlecka, Tetrahedron: Asymmetry 1999 10, 3457-3461.

611 [35] C. Yang, Q. Jin, H. Zhang, J. Liao, J. Zhu, B. Yu, J. Deng, Green Chem. 2009, $11,1401-1405$.

[36] A. Rostami, J. Akradi, Tetrahedron Lett. 2010, 51, 3501-3503.

[37] F. Secci, A. Frongia, P. P. Piras, Tetrahedron Lett. 2014, 55, 603-605.

[38] A. Bottoni, M. Calvaresi, A. Ciogli, B. Cosimelli, G. Mazzeo, L. Pisani, E. 616 Severi, D. Spinelli, S. Superchi, Adv. Synth. Catal. 2013, 355, 191-202.

[39] Z.-H. Zhang, X.-S. Yang, Q.-Q. Zhang, L. Wang, M.-Y. He, Q. Chen, X.-F. Huang, RSC Adv. 2016, 6, 104036-104040.

[40] N. Deak, P. M. Petrar, S. Mallet-Ladeira, L. Silaghi-Dumitrescu, G. Nemeş, D. Madec, Chem. Eur. J. 2016, 22, 1349-1354.

621 [41] M. Mehring, M. Schürmann, K. Jurkschat, Organometallics 1998, 17, 1227-1236.

[42] N. Deak, I.-T. Moraru, N. Saffon-Merceron, D. Madec, G. Nemes, Eur. J. Inorg. Chem. 2017, 4214-4220.

[43] N. Deak, O. Thillaye du Boullay, I.-T. Moraru, S. Mallet-Ladeira, D. Madec, 626 G. Nemes, Dalton Trans. 2019, 48, 2399-2406.

[44] N. Lentz, S. Mallet-Ladeira, A. Baceiredo, T. Kato, D. Madec, Dalton Trans. 2018, 47, 15751-15756.

[45] R. H. Zhang, Y. L. Zhan, J. T. Chen, Synth. React. Inorg. Met. Chem. 1995, 25, 283-292.

631 [46] P. E. Gormisky, M. C. White, J. Am. Chem. Soc. 2011, 133, 12584-12589.

[47] F. Liu, X. Q. Luo, B. A. Song, P. S. Bhadury, S. Yang, L. H. Jin, W. Xue, D. Y. Hu, Bioorg. Med. Chem. 2008, 16, 3632-3640.

[48] A. L. Fuller, R. A. Aitken, B. M. Ryan, A. M. Z. Slawin, J. D. Woollins, J. Chem. Crystallogr. 2009, 39, 407-415.

636 [49] F. Naso, C. Cardellicchio, M. A. M. Capozzi, F. Capitelli, V. Bertolasi, New J. Chem. 2006, 30, 1782-1789.

[50] F. H. Allen, O. Kennard, D. G. Watson, L. Brammer, A. G. Orpen, R. Taylor, J. Chem. Soc., Perkin Trans. 2 1987, 1-19.

[51] D. R. Rayner, E. G. Miller, P. Bickart, A. J. Gordon, K. Mislow, J. Am. Chem. 641 Soc. 1966, 88, 3138-3139.

[52] D. R. Rayner, A. J. Gordon, K. Mislow, J. Am. Chem. Soc. 1968, 90, 48544860.
[53] E. G. Miller, D. R. Rayner, H. T. Thomas, K. Mislow, J. Am. Chem. Soc. 1968, 90, 4861-4868.

[54] P. Bickart, F. W. Carson, J. Jacobus, E. G. Miller, K. Mislow, J. Am. Chem. 646 Soc. $1968,90,4869-4876$.

[55] H. Marom, P. U. Biedermann, I. Agranat, Chirality 2007, 19, 559-569.

[56] D. Matioszek, T.-G. Kocsor, A. Castel, G. Nemes, J. Escudié, N. Saffon, Chem. Commun. 2012, 48, 3629-3631.

[57] T. G. Kocsor, D. Matioszek, G. Nemeş, A. Castel, J. Escudié, P. M. Petrar, N. 651 Saffon, I. Haiduc, Inorg. Chem. 2012, 51, 7782-7787.

[58] T.-G. Kocsor, G. Nemes, N. Saffon, S. Mallet-Ladeira, D. Madec, A. Castel, J. Escudié, Dalton Trans. 2014, 43, 2718-2721.

[59] R. Septelean, I.-T. Moraru, T.-G. Kocsor, N. Deak, N. Saffon-Merceron, A. Castel, G. Nemes, Inorg. Chim. Acta 2018, 475, 112-119.

[60] N. Deak, D. Madec, G. Nemes, Eur. J. Inorg. Chem. 2020, DOl:https:// doi.org/10.1002/ejic.202000409.

[61] M. Henn, V. Deáky, S. Krabbe, M. Schürmann, M. H. Prosenc, S. HerresPawlis, B. Mahieu, K. Jurkschat, Z. Anorg. Allg. Chem. 2011, 637, 211-223.

[62] a) K. Peveling, M. Schürmann, R. Ludwig, K. Jurkschat, Organometallics 661 2001, 20, 4654-4663; b) K. Peveling, M. Schürmann, K. Jurkschat, Main Group Met. Chem. 2001, 24, 251-252; c) M. Mehring, K. Jurkschat, M. Schürmann, Main Group Met. Chem. 1998, 21, 635-642.

[63] Phosphorus-31 NMR Spectroscopy, (Ed.: O. Kühl), Springer-Berlin-Heidelberg, Berlin, Heidelberg, 2009, ISBN 978-3-540-79118-8.

[64] R. Septelean, H. Ranaivonjatovo, G. Nemes, J. Escudié, I. Silaghi-Dumitrescu, H. Gornitzka, L. Silaghi-Dumitrescu, S. Massou, Eur. J. Inorg. Chem. 2006, 4237-4241.

[65] Bruker, SAINT and SADABS, Bruker AXS Inc., Madison, Wisconsin, USA.

[66] G. M. Sheldrick, Acta Crystallogr., Sect. A 2008, 64, 112-122.

[67] G. M. Sheldrick, Acta Crystallogr., Sect. C 2015, 71, 3-8.

[68] M. J. Frisch, G. W. Trucks, H. B. Schlegel, G. E. Scuseria, M. A. Robb, J. R. Cheeseman, G. Scalmani, V. Barone, B. Mennucci, G. A. Petersson, H. Nakatsuji, M. Caricato, X. Li, H. P. Hratchian, A. F. Izmaylov, J. Bloino, G. Zheng, J. L. Sonnenberg, M. Hada, M. Ehara, K. Toyota, R. Fukuda, J. Hase- 676 gawa, M. Ishida, T. Nakajima, Y. Honda, O. Kitao, H. Nakai, T. Vreven, J. A. Montgomery Jr., J. E. Peralta, F. Ogliaro, M. Bearpark, J. J. Heyd, E. Brothers, K. N. Kudin, V. N. Staroverov, R. Kobayashi, J. Normand, K. Raghavachari, A. Rendell, J. C. Burant, S. S. lyengar, J. Tomasi, M. Cossi, N. Rega, J. M. Millam, M. Klene, J. E. Knox, J. B. Cross, V. Bakken, C. Adamo, J. 681 Jaramillo, R. Gomperts, R. E. Stratmann, O. Yazyev, A. J. Austin, R. Cammi, C. Pomelli, J. W. Ochterski, R. L. Martin, K. Morokuma, V. G. Zakrzewski, G. A. Voth, P. Salvador, J. J. Dannenberg, S. Dapprich, A. D. Daniels, Ö. Farkas, J. B. Foresman, J. V. Ortiz, J. Cioslowski, D. J. Fox, Gaussian 09, Revision E.01, Gaussian, Inc., Wallingford CT, 2009.

[69] A. V. Marenich, C. J. Cramer, D. G. Truhlar, J. Phys. Chem. B 2009, 113, 6378-6396.

[70] C. Adamo, V. Barone, J. Chem. Phys. 1999, 110, 6158-6170.

[71] a) A. Schäfer, C. Huber, R. Ahlrichs, J. Chem. Phys. 1994, 100, 5829; b) D. Rappoport, F. Furche, J. Chem. Phys. 2010, 133, 134105.

[72] D. A. McQuarrie, J. D. Simon, Molecular thermodynamics, University Science Book, Sausalito, 1999, ISBN-13: 978-1891389054.

Received: July 30, 2020 